\title{
Exhaust emissions and fuel consumption in a chassis dynamometer load test in the aspect of modification of an engine controlling system
}

The article presents calculations of exhaust emissions and fuel consumption under test conditions on a chassis dynamometer test bench. The study describes the realization of the tests and the methodology of the calculation of the exhaust gas flow and the estimation of the fuel consumption based on exhaust emissions. The presented research results and their analysis describe the emission scale of selected gaseous fumes components during full engine load and the fuel consumption associated with such tests. Similar emissions occur during a rapid acceleration of a vehicle in road conditions.

Key words: emission tests, $\mathrm{CO}_{2}$ emissions, fuel consumption, chassis dynamometer, vehicle load tests

\section{Introduction}

Considering a very wide spectrum of automotive impact on the environment, many problems still need to be analyzed and resolved. Emissions and road noise issues are still significant, especially at the stage of dynamic development of road infrastructure in Poland. Exhaust gases toxic components emission become a serious nuisance of most Polish cities. Photochemical smog is no longer just a problem of large Silesian agglomerations, but it is also known in Cracow, Poznan, Warsaw or Lublin. The effects of the presence of transport are very burdensome also outside the cities. Between the years 2010 and 2014, the length of national roads and motorways increased twice, reaching 1488 $\mathrm{km}$ and $1556 \mathrm{~km}$ at the end of 2014 [1]. Roads are built into new areas and introduce hazardous emissions and noise which is particularly important for high speed routes. Acoustic screens are being built to minimize the noise consequences but their aesthetics and landscape composition are not sufficient enough. Acoustic screens, apart from their technical function, should be as natural as possible, which can be achieved using the appropriate plant species [2]. These solutions have a more natural look and can also assimilate gaseous pollutants.

Other serious hazards that have grown up in recent years are problems with the utilization of automotive used fluids. Studies on used engine oils exploited in tractors and agricultural machinery indicate that these oils are only slightly recycled and that a huge part of them goes directly into the environment. The problem is very important because the oils are very harmful due to heavy metals content and other mutagenic impurities [3].

Changes in Poland after accession to the European Union influenced the total number of vehicles has doubled. The expansion and modernization of the machine park has been noted also in agriculture. As for a number of cars (513 units) per 1000 inhabitants we are typical Europeans. It is estimated that the number of passenger cars in Poland is over 20 million [4]. Many of them are in possession of young people who, use the opportunity to work abroad during the holiday season, and then buy cars and bring them to Poland.

As the number of vehicles increases, there is a growing demand for automotive services, not only for vehicle repair but also for their modifications. The modifications that can be seen at a first sight are external, but more often, it is about to improve the dynamic or economics of an engine. In order to properly perform such upgrades, a special equipment is needed to measure the effectiveness of the treatments [5]. Chassis dynamometer is an example of such devices. There were several stands of this type in Poland at the beginning of the century. Nowadays they are becoming increasingly popular for diagnostic reasons as they allow vehicles to be tested under load conditions in a laboratory without the need for road test drives which are less susceptible to perform measurements. The capabilities offered by chassis dynamometers greatly enhance the process of diagnosing the technical condition of an engine and a powertrain system. Moreover a proper regulation of a gas powered engine also requires appropriate testing, not only in aspect of its dynamic performance, but also in terms of emission of harmful exhaust components and fuel consumption.

The results of emission measurements obtained during load tests are very interesting. Examples of such tests can be found in the literature [6]. It should be noticed that such loads can also be present in road conditions, during intense vehicle acceleration. It is very important that the results significantly differ from the emission levels of given components commonly reported in the results of homologation tests or road tests [7-10].

\section{The objective and scope of research}

The purpose of the study was to determine the mass of exhaust gases emitted to the environment and the fuel consumption during load tests related to the determination of engine performance characteristics with use of a chassis dynamometer test bench.

The paper presents the load tests realization and the results of exhaust emission tests for two twin vehicles, one of which has been modified in the area of the engine controller. Results of exhaust emissions and fuel consumption were obtained by calculations based on the volumetric shares of selected exhaust components, measurement of intake manifold air flow and on the basis of the carbon balance method.

The scope of measurements included registration of several parameters such as: 
- power on wheels $-\mathrm{N}_{\mathrm{w}},(\mathrm{kW})$,

- power loss $\mathrm{N}_{\mathrm{l}},(\mathrm{kW})$,

- engine speed $-\mathrm{n},\left(\mathrm{min}^{-1}\right)$,

- engine oil temperature $-\mathrm{T},\left({ }^{\circ} \mathrm{C}\right)$,

- stream of air mass flowing through the intake manifold $-\mathrm{q}_{\mathrm{air}},\left(\mathrm{g} \cdot \mathrm{s}^{-1}\right)$,

- volumetric shares of gaseous exhaust components - $\mathrm{CO}$, $\mathrm{CO}_{2}, \mathrm{O},(\%)$ and $\mathrm{HC}, \mathrm{NO}_{\mathrm{x}}$, (ppm).

\section{Methods of research}

Two similar vehicles Skoda Octavia $1 \mathrm{U}$ were the objects of the study. Each vehicle was fitted with a $1.9 \mathrm{dm}^{3}$ direct-injection turbodiesel ASV engine of maximum torque $235 \mathrm{Nm}$ at $1900 \mathrm{~min}^{-1}$ ) and maximum power output of $81 \mathrm{~kW}$ at $4150 \mathrm{~min}^{-1}$. The engines were equipped with exhaust gas recirculation system, variable turbine geometry (VTG) and reactor DOC (Diesel Oxidation Catalysts). Vehicles were of similar age (A - 2002 and B - 2001), while the mileage indicated by the odometer was slightly different (A - 253,000 km, B - 226,000 km). Before the measurements, the vehicles were diagnosed and approved for further testing. It should be noted that in the case of a vehicle $\mathrm{B}$, there has been previously incorporated software modifications into the engine controller to raise the maximum torque and the maximum power output. Each vehicle had been produced to comply with Euro 3 standard but the exploitation process and the modifications could change that.

After the tested vehicle was installed at the test stand, a gas analyzer and a data link cable were connected to the vehicle. Engine oil temperature and cooling air were also monitored. Next, a steady load driving test was carried out to bring up the engine to a stabilized heat state. Prior to the proper measurement unnecessary energy consuming devices has been switched off and then the load test with the data registration begun.

Vehicle tests were carried out using MAHA's MSR 500 chassis dynamometer, dedicated for vehicles with a maximum engine power up to $250 \mathrm{~kW}$. This is a one-drum stand with a drum diameter of $500 \mathrm{~mm}$, which can work in a discrete or load mode. The second mode, due to the way the measurement is carried out, is similar to the inertia method, but in addition to the inertia mass of the accelerated wheels and rollers, an additional brake load is added. This type of dynamometer work was used due to its similarity to an intensive acceleration in road conditions. The device in this mode performs a measurement of the rotational speed of the rollers driven by the vehicle wheels. The same time electronically controlled eddy-current brakes introduce additional load to the rollers an wheels [11, 12].

For the person conducting the test its procedure is reduced to accelerating the vehicle on the test stand with the use of fourth or fifth gear at fully pressed acceleration pedal. Then, after reaching the maximum speed for a given gear, the clutch is disengaged and free-run is being performed to measure the power loss in the powertrain system. So the test method is similar to inertial road tests [5].

Another instrument used in the study was the MAHA MGT5 vehicle exhaust gas analyzer, which allows continuous measurement of the volumetric shares of five exhaust components. It has been classified by OIML (Organization Internationale de Métrologie Légale) as a 0 Class analyzer. The manufacturer of the chassis dynamometer and the analyzer provided the possibility of their cooperation, so the results of the measurement of the exhaust gas composition were recorded using dedicated software.

The procedure utilizes a vehicle diagnostic system and a DLC (Data Link Connector) interface. When the vehicle is connected to the control panel of the dynamometer, the information about the engine operating parameters can be recorded and used for further calculations. In this case the most important were the signals from the engine crankshaft speed sensor and the mass air flow meter. It should be added that thanks to the above mentioned communication with the vehicle controller via the DLC connector it is also possible to register the engine operating parameters in the road traffic conditions. The results of such tests can also be used to evaluate the vehicle dynamic parameters and to determine the external characteristics of an engine - similarly to the chassis dynamometer $[5,13]$.

\section{Methods of calculations}

A number of conversions were made to determine the fuel consumption and emissions. Due to the equipment and methods used, the calculations required some assumptions and simplifications.

The exhaust gas analyzer used in the studies performs measurements of the volumetric shares of selected exhaust components. The shares combined with the information about the exhaust gas flow give an opportunity to learn about the amount of given gas emitted. However, the amount of exhaust can be determined by taking into account the air flowing through the engine intake manifold and the fuel dose. The mass of exhaust gases is the sum of the mass of air and the fuel to be burned. Instead of the direct information about the fuel dose, the composition of the exhaust gases can be used to determine the excess air factor $\lambda$ and then to make the necessary calculations.

By default, the value of $\lambda$ is determined by assumption that the fuel is petrol, for which the substitution formula can be written as $\mathrm{C}_{1} \mathrm{H}_{1.7261} \mathrm{O}_{0.0175}$ [14]. Diesel fuel with substitution formula $\mathrm{C}_{1} \mathrm{H}_{1.86} \mathrm{O}_{0.005}$ [15] has a different composition and therefore the values $\lambda$ calculated automatically by the analyzer cannot be used. The measured $\mathrm{CO}, \mathrm{CO}_{2}, \mathrm{HC}, \mathrm{O}_{2}$ and $\mathrm{NO}_{\mathrm{x}}$ volumetric concentrations and the Brettschneider formula should be used to determine the correct value of the excess air ratio [14-16]. The next step is to determine the volumetric shares of $\mathrm{N}_{2}, \mathrm{H}_{2} \mathrm{O}$ and Ar to complement the information on the composition of the exhaust gases. The shares of these components can be obtained basing on the combustion reaction for hydrocarbon fuel with air $(\lambda>1)$. The relations between volumetric and mass ratios of the exhaust gaseous components and the mass of exhaust gases were calculated as in the cited literature [16]. Calculations were performed for each set of data recorded during the measurements.

For example, for engine $\mathrm{A}$, when the speed reached $3000 \mathrm{~min}^{-1}$ and the torque and engine power were respectively $237.08 \mathrm{Nm}$ and $74.48 \mathrm{~kW}$, the excess air factor $\lambda$ reached the instantaneous value of 1.555 . This value was 
determined based on the instantaneous composition of the exhaust gas registered for the mentioned conditions and for the given fuel $\left(\mathrm{C}_{1} \mathrm{H}_{1.86} \mathrm{O}_{0.005}\right)$. The reaction of the combustion process took the form (1), where the individual coefficients determine the moles of the component.

$$
\begin{aligned}
& \mathrm{C}_{1} \mathrm{H}_{1.86} \mathrm{O}_{0.005}+2.274 \cdot \mathrm{O}_{2}+8.449 \cdot \mathrm{N}_{2}+0.108 \cdot \mathrm{Ar} \rightarrow \\
& \rightarrow 1 \cdot \mathrm{CO}_{2}+0.930 \cdot \mathrm{H}_{2} \mathrm{O}+8.449 \cdot \mathrm{N}_{2}+0.108 \cdot \mathrm{Ar}+0.812 \cdot \mathrm{O}_{2}
\end{aligned}
$$

Taking into account individual coefficients for combustion products and treating their sum as $100 \%$, the molar ratios of the given components were determined, respectively: $8.23 \%-\mathrm{H}_{2} \mathrm{O}, 8.85 \%-\mathrm{CO}_{2}, 74.77 \%-\mathrm{N}_{2}, 0.96 \%-$ Ar and $7.19 \%-\mathrm{O}_{2}$. These are the main components of the exhaust gas of a diesel engine that works with excess of air. These calculations do not take into account information about shares of other exhaust components than mentioned above, which are due to imperfections in the real combustion process. It was, however, simplified and assumed that their shares were small and did not significantly affect the overall exhaust flow. Subsequently, molar masses and determined molar proportions were used to obtain the mass shares of the given components. Summing up results in the time domain, the total masses of the emitted gaseous components (including carbon monoxide and carbon dioxide) were determined.

\section{Fuel consumption}

Two-way reasoning can be used to determine the fuel consumption. First way (by lambda) sets that we know the stoichiometry of the burning process. Basing on the formula for diesel fuel $\left(\mathrm{C}_{1} \mathrm{H}_{1.86} \mathrm{O}_{0.005}\right)$ and the combustion reaction for the stoichiometric mixture $(\lambda=1)$ the air-fuel ratio (AFR) equals 14.46. That means that the mass of exhaust gas is greater than the mass of air by the mass of fuel, which in this case is $1 / 14.46$ of the mass of air. However, the tested diesel engine operates with an excess of air and therefore the actual composition of the air/fuel mixture can become known if the right value of $\lambda$, determined by the composition of the fumes, is used.

The other way (by carbon) leads to similar data that can be obtained using the carbon dioxide and carbon monoxide emissions. It can be assumed that the emissions are results of burning fuel of known composition. If, during the test, as a result of burning of the fuel given with formula $\mathrm{C}_{1} \mathrm{H}_{1.86} \mathrm{O}_{0.005}$, the engine emits mass of carbon dioxide $\mathrm{m}_{\mathrm{CO} 2}$ and mass of carbon monoxide $\mathrm{m}_{\mathrm{CO}}$, then basing on the molar masses of the substances, the mass of fuel necessary to achieve the $\mathrm{CO}$ and $\mathrm{CO}_{2}$ emissions can be calculated. The number of moles of carbon introduced with the fuel equals the sum of the moles of carbon dioxide and carbon monoxide produced by the combustion. In turn, the number of moles of fuel is the mass of fuel consumed divided by the molar mass of the fuel. Similarly, the number of moles of carbon dioxide is the mass of carbon dioxide divided by its molar mass. The same is true for carbon monoxide. According to that, the mass of fuel consumed can be expressed by the dependence (2).

$$
\mathrm{m}_{\text {fuel }}=\mu_{\text {fuel }} \cdot\left(\frac{\mathrm{m}_{\mathrm{CO}_{2}}}{\mu_{\mathrm{CO}_{2}}}+\frac{\mathrm{m}_{\mathrm{CO}}}{\mu_{\mathrm{CO}}}\right)
$$

where: $\mathrm{m}_{\text {fuel }}-$ mass of fuel consumed, $(\mathrm{g}), \mathrm{m}_{\mathrm{CO}}, \mathrm{m}_{\mathrm{CO} 2}-$ mass of emitted carbon monoxide and carbon dioxide, $(\mathrm{g}), \mu_{\text {fuel }}-$ molar mass of the substitution fuel molecule, $\left(\mathrm{g} \cdot \mathrm{mol}^{-1}\right), \mu_{\mathrm{CO}}$, $\mu_{\mathrm{CO} 2}-$ molar mass of carbon monoxide and carbon dioxide, $\left(\mathrm{g} \cdot \mathrm{mol}^{-1}\right)$.

\section{Measurement results}

As the results of measurements and calculations, the fuel consumption and mass emissions of the selected components of the exhaust gases were determined for two twin diesel engines, one of which was modified by the engine control software (engine B). Calculations and analysis of the results were narrowed to a common rotational speed range of $1450 \mathrm{~min}^{-1}$ to $4050 \mathrm{~min}^{-1}$. The power characteristics $\mathrm{N}$ and torques $\mathrm{M}$ of the tested engines were supplemented by the air mass flow through the intake manifold (Fig. 1) and the volumetric ratios of selected gaseous fumes components (Fig. 2) and presented as functions of rotational speed $n$.

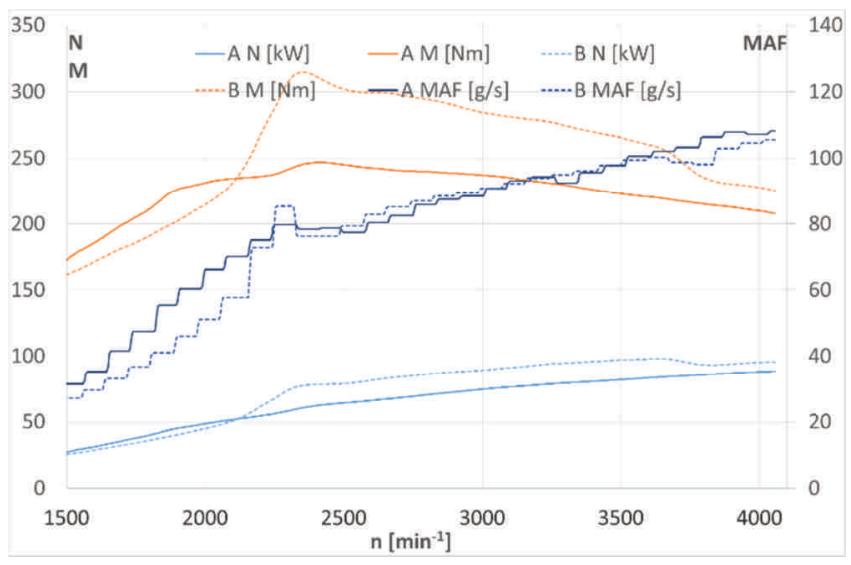

Fig. 1. Power, torque and air flow during the test for engines A and B

Table 1. Results of the tests and calculations

\begin{tabular}{|l|c|c|c|c|}
\hline Parameter & Symbol & Unit & $\begin{array}{c}\text { Engine } \\
\mathrm{A}\end{array}$ & $\begin{array}{c}\text { Engine } \\
\mathrm{B}\end{array}$ \\
\hline Power max & $\mathrm{N}_{\max }$ & $\mathrm{kW}$ & 88.3 & 97.9 \\
\hline Engine speed of $\mathrm{N}_{\max }$ & $\mathrm{n}_{\mathrm{N}}$ & $\mathrm{min}^{-1}$ & 4050 & 3650 \\
\hline Torque max & $\mathrm{M}_{\max }$ & $\mathrm{Nm}^{1}$ & 246.8 & 314.7 \\
\hline Engine speed of $\mathrm{M}_{\max }$ & $\mathrm{n}_{\mathrm{M}}$ & $\mathrm{min}^{1}$ & 2400 & 2350 \\
\hline Mass of Fumes & $\mathrm{m}_{\text {fume }}$ & $\mathrm{kg}$ & 2.512 & 2.452 \\
\hline Mass of $\mathrm{CO}_{2}$ & $\mathrm{~m}_{\mathrm{CO} 2}$ & $\mathrm{~kg}$ & 0.374 & 0.433 \\
\hline Mass of $\mathrm{O}_{2}$ & $\mathrm{~m}_{\mathrm{O} 2}$ & $\mathrm{~kg}$ & 0.205 & 0.109 \\
\hline Mass of $\mathrm{CO}$ & $\mathrm{m}_{\mathrm{CO}}$ & $\mathrm{g}$ & 0.603 & 5.367 \\
\hline Mass of $\mathrm{HC}$ & $\mathrm{m}_{\mathrm{HC}}$ & $\mathrm{g}$ & 0.028 & 0.001 \\
\hline Mass of $\mathrm{NO} \mathrm{X}_{\mathrm{X}}$ & $\mathrm{m}_{\mathrm{NOx}}$ & $\mathrm{g}$ & 2.749 & 3.209 \\
\hline Mass of fuel (by carbon) & $\mathrm{m}_{\text {fuel }}$ & $\mathrm{kg}$ & 0.119 & 0.140 \\
\hline Volume of fuel (by carbon) & $\mathrm{V}_{\text {fuel }}$ & $\mathrm{dm}$ & 0.142 & 0.167 \\
\hline Mass of fuel (by lambda) & $\mathrm{m}_{\text {fuel } \lambda}$ & $\mathrm{kg}^{3}$ & 0.110 & 0.131 \\
\hline Volume of fuel (by lambda) & $\mathrm{V}_{\text {fuel } \lambda}$ & $\mathrm{dm}^{3}$ & 0.131 & 0.156 \\
\hline
\end{tabular}

The tests results and further calculations have been gathered in Table 1. The data show that an approximately $90 \mathrm{~kW}$ diesel engine during ca. 30 seconds of a full power load test at the chassis dynamometer utilizes about $150 \mathrm{ml}$ of diesel fuel of $0.84 \mathrm{~kg} \cdot \mathrm{dm}^{-3}$ density. More details can be found by analyzing additional graphs (Figs 1-4).

By the analysis of the data presented in Fig. 1 it can be followed that the engine with modified control software 
develops about $27 \%$ higher torque and about $11 \%$ higher maximal power than the unmodified one. Simultaneously, it can be also seen that the maximum power in case of engine $\mathrm{B}$ appears at lower rotational speed $\left(3650 \mathrm{~min}^{-1}\right)$. It is also important that in the speed range of 1500 to $2100 \mathrm{~min}^{-1}$, the modified engine torque is lower than the factory one. In the rest of the observed speed range the modified engine torque is higher. That can be affected by similar changes of the mass air flows for the engines. These are due to differences in the turbochargers operating ways of those engines. In case of engine $\mathrm{B}$ the characteristic drop of torque is observed at speed of $3750 \mathrm{~min}^{-1}$. It is implicated by a drop of air mass flow observed simultaneously and influences the drop of power drop. These also affect the final exhaust emissions presented in Table 1.

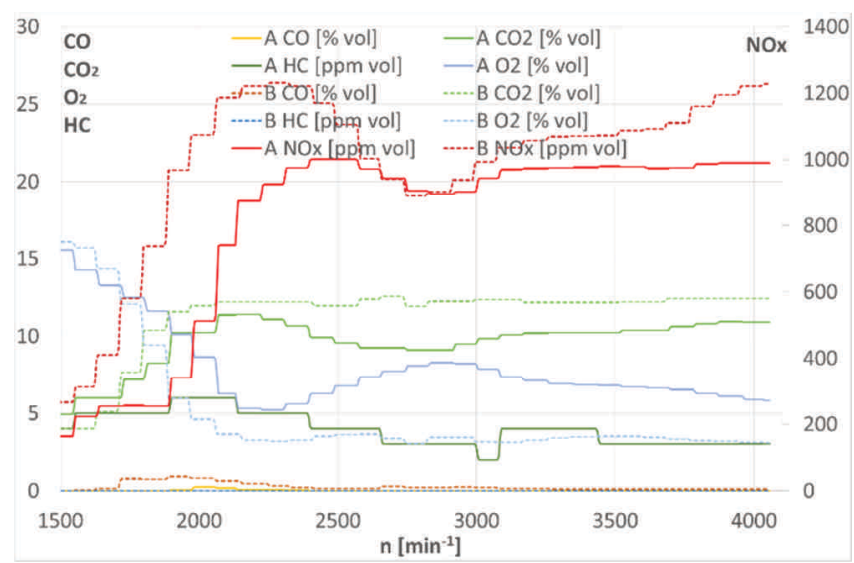

Fig. 2. Volumetric shares of the measured compounds during the test of engines $\mathrm{A}$ and $\mathrm{B}$

In Fig. 2, changes in volumetric proportions of selected components of the exhaust gases recorded during the test can be observed. There are differences in emissions of individual components resulting from increased fuel doses for engine $\mathrm{B}$, which are strongly reflected in $\mathrm{CO}_{2}$ and $\mathrm{O}_{2}$ emissions. The maximum values for $\mathrm{CO}_{2}$ are for engines $\mathrm{A}$ and $\mathrm{B}$ respectively $11.4 \%$ and $12.57 \%$. It can be noticed that $\mathrm{CO}_{2}$ content varies about $2-3 \%$ for engine $\mathrm{A}$ and for engine B it mainly stays constant (ca. 12.5\%). In case of engine A oxygen presence drops to $5 \%$ at $2200 \mathrm{~min}^{-1}$ and then raises to about $8 \%$ at $2900 \mathrm{~min}^{-1}$ and then slightly drops to $6 \%$. In case of engine $\mathrm{B}$ oxygen content drops to $3.5 \%$ at $2100 \mathrm{~min}^{-1}$ and stays close to that level till the end of the test. The shares of $\mathrm{CO}_{2}$ and $\mathrm{O}_{2}$ for engine $\mathrm{B}$ can confirm a tuner's efforts to utilize the oxygen maximally. The changes in combustion conditions (local mixture enrichment, higher pressure, higher temperature) are also seen in emissions of $\mathrm{CO}(\mathrm{A}-\max 0.24 \%$ and $\mathrm{B}-\max 0.93 \%$ ) and $\mathrm{NO}_{\mathrm{x}}(\mathrm{A}-\max 1001 \mathrm{ppm}$ and $\mathrm{B}-\max 1232 \mathrm{ppm})$.

Fig. 3 illustrates the changes in the proportions of the main components of the exhaust gases emitted by engine B. Compared to Fig. 2, the illustration (Fig. 3) also includes data on the volumetric shares of $\mathrm{N}_{2}, \mathrm{H}_{2} \mathrm{O}$ and Ar. The shares were obtained basing on the substitution fuel formula $\mathrm{C}_{1} \mathrm{H}_{1.86} \mathrm{O}_{0.005}$, calculated air excess coefficient $\lambda$, assumed air composition and the formula of the combustion process reaction. The high level of water vapor content (ca. 11\%) and the low content of oxygen (ca. 3\%) can suggest that the tuner did his best to uncover the potential power of the engine. It also indicates that the modified engine is very close to the smoke limit.

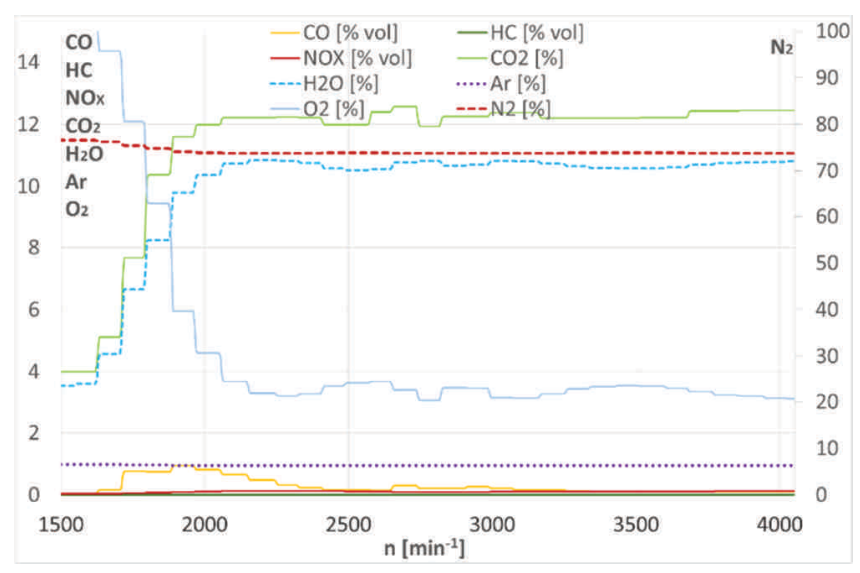

Fig. 3. Calculated volumetric shares of the main fumes compounds for the test of engine $B$

A summary of the measurements and performed calculations is illustrated in Fig. 4 showing the masses of the selected exhaust gas components emitted during the comparative tests of the engines.

It should be noted that the value of overall exhaust gas emissions should be similar for the compared engines. These engines are loaded at the same time and at the same rotational speed range. The displacement capacity and the boost systems are the same and should result in similar mass of pumped gases.

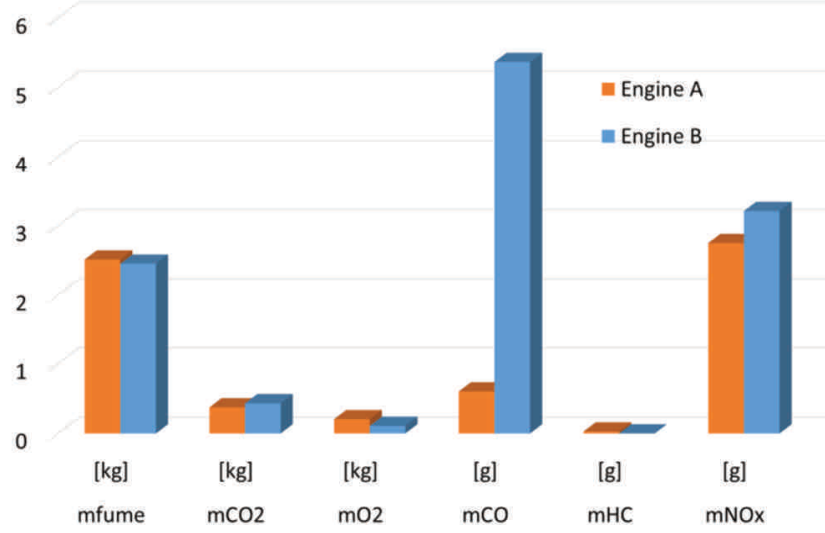

Fig. 4. Mass of the fumes compounds emitted during the test for engines A and $\mathrm{B}$

In this case, however, we have to deal with separate objects of different technical stages, and hence the differences observed in the total mass of the exhaust gases can also be observed. Designated values $(2.512 \mathrm{~kg}$ and $2.452 \mathrm{~kg}$ ) indicate that the unmodified engine (A) emits slightly more (about $2.4 \%$ ) of exhaust gases than the modified engine (B). This is due to the greater amount of air supplying engine $\mathrm{A}$ what can be noticed in the initial test phase (Fig. 1).

The next results obtained for the several exhaust components are already in line with the predictions. The $\mathrm{CO}_{2}$ mass is about $16 \%$ higher for the modified engine (B), and 
translates into an increase in its power. The increase in $\mathrm{CO}_{2}$ emissions correlates significantly with the decrease in $\mathrm{O}_{2}$ emission, too. In the case of the modified engine, the higher $\mathrm{CO}$ (about 9 times) and $\mathrm{NO}_{\mathrm{x}}$ (about twice) emissions confirm the deterioration of the combustion process conditions.

\section{Summary and conclusions}

Load tests related to the designation of an engine external (operational) characteristics resemble extreme loads that may occur on the road. However, they differ significantly from the conditions of homologation tests, but one can try to compare them by specifying the emissions in relation to the distance traveled. Regarding the speed at the roller stand, it was found that the vehicles drove about $850 \mathrm{~m}$ during the test period.

Comparing the test results to vehicle manufacturer data $\left(\mathrm{CO}_{2}-135 \mathrm{~g} / \mathrm{km}\right)$ and the limits resulting from the approval standard (Euro3; $\mathrm{CO}-0.64 \mathrm{~g} / \mathrm{km}$ and $\mathrm{NO}_{\mathrm{x}}-0.50 \mathrm{~g} / \mathrm{km}$ [17]) it obviously should be noted that in case of both cars the analyzed load test period results in significantly higher $\mathrm{CO}_{2}$ emissions due to the maximal load. The real distance traveled during the test is about $850 \mathrm{~m}$, but due to the manufacturer's declared $\mathrm{CO}_{2}$ emissions it corresponds to driving of about $3.25 \mathrm{~km}$ for engine $\mathrm{A}$ and about $3.77 \mathrm{~km}$ for $\mathrm{B}$. In case of engine $A$ the emission of $C O$ reaches $0.71 \mathrm{~g} / \mathrm{km}$, whereas in case of engine $\mathrm{B}$ it is ca. nine times higher (6.31 $\mathrm{g} / \mathrm{km})$. Emissions of $\mathrm{NO}_{\mathrm{x}}(\mathrm{A}-3.23 \mathrm{~g} / \mathrm{km}$ and $\mathrm{B}-3.77$ $\mathrm{g} / \mathrm{km}$ ) are also high and corresponds to a distance of about 7 $\mathrm{km}$.

It should be emphasized, however, that the comparison to the abovementioned limits (Euro 3 ) is just indicative and that the standard limits are not foreseen for emission tests during determining engines external characteristics.

Moreover, the following conclusions can be drawn regarding the two engines and the selected parameters of their performances and exhaust emissions:
- engine with modified control software develops about $27 \%$ higher torque and about $11 \%$ higher power than unmodified one,

- increase in engine power is occupied by increased fuel consumption, which is calculated by carbon balance higher by approx. 18\% (according to the lambda coefficient the difference is about $19 \%$ ),

- considerations for calculating fuel consumption based on $\mathrm{CO}_{2}$ emissions can be used in reverse, i.e. when estimating $\mathrm{CO}_{2}$ emissions based on fuel consumption,

- the effect of enrichment of the fuel mixture (fuel dose) in case of engine $\mathrm{B}$ is clearly observed in emitted $\mathrm{CO}$ and $\mathrm{CO}_{2}$ - in case of carbon monoxide the emitted mass is nearly nine times greater than in case of engine $\mathrm{A}$,

- the emission of nitrogen oxides is also higher (by 17\%), it can be explained by the influence of the air/fuel mixture enrichment, which implicates the increase of maximum temperature and maximum pressure in the combustion chamber - the parameters mostly responsible for nitrogen oxides formation,

- in case of engine B the lower overall mass of the exhaust gases is observed in the test. It is certainly the result of similar difference in the air supplying mass flow. The difference of the flow noticed within the speed range from 1500 to $2100 \mathrm{~min}^{-1}$ may be an effect of changed regulation of the turbocharger.

Referring to the research and methods employed, it should be stressed that the mass of the components emitted depends on the method of carrying out the load test. The longer period the engine is being loaded, the greater amount of mass of the exhaust gases is emitted. It is very important in any comparisons of emissions based on tests performed on different dynamometer test stands.

\section{Nomenclature}

AFR air/fuel ratio

$\mathrm{CO}$ carbon monoxide

$\mathrm{CO}_{2}$ carbon dioxide

DLC data link connector

HC hydrocarbons
$\mathrm{NO}_{\mathrm{X}}$ nitrogen oxides

OIML Organization Internationale de Métrologie Légale

$\lambda \quad$ excess air coefficient

\section{Bibliography}

[1] GUS, Transport/Ogółem/Sieć komunikacyjna, 2014. [Online]. Available: swaid.stat.gov.pl/TransportLacznosc_ dashboards/Raporty_predefiniowane/RAP_DBD_TRANS_ 2.aspx (accessed: 03.01.2017).

[2] SZYSZLAK-BARGŁOWICZ, J., SŁOWIK, T., ZAJĄC, G., PIEKARSKI, W. Inline plantation of virginia mallow (Sida hermaphrodita R.) as biological acoustic screen, Rocznik Ochrona Srodowiska. 2013, 15(1).

[3] ZAJĄC, G., SZYSZLAK-BARGŁOWICZ, J., SŁOWIK, T. et al. Designation of chosen heavy metals in used engine oils using the XRF method. Polish Journal of Environmental Studies. 2015, 24(5).

[4] GUS, Transport/Drogowy/Pojazdy drogowe, 2014. [Online]. Available: swaid.stat.gov.pl/TransportLacznosc_dashboards/
Raporty_predefiniowane/RAP_DBD_TRANS_7.aspx (accessed: 03.01.2017).

[5] KURANC, A. Badania mocy silnika pojazdu z wykorzystaniem metod inercyjnych. Autobusy: technika, eksploatacja, systemy transportowe. 2012, 13.

[6] WENDEKER, M., GĘCA, M., BARAŃSKI, G., SOCHACZEWSKI, R. Badania pojazdu EURO 5 przy pełnym obciążeniu silnika. Autobusy: technika, eksploatacja, systemy transportowe. 2012, 13.

[7] COLLINS, J.F., SHEPHERD, P., DURBIN, T.D. et al. Measurements of in-use emissions from modern vehicles using an on-board measurement system. Environmental Science \& Technology. 2007, 41(18).

[8] MAZANEK, A. Badania porównawcze emisji toksycznych składników gazów wylotowych z silnika o zapłonie samoczynnym zasilanego ON i B10. Nafta-Gaz. 2010, 66(9). 
[9] MERKISZ, J., ANDRZEJEWSKI, M., PIELECHA, J. The effect of applying the eco-driving rules on the exhaust emissions. Combustion Engines. 2013, 155(4).

[10] NITA, J., BORCZUCH, A. Preliminary evaluation of correlation of CVS and modal techniques in homologation tests of vehicle with regard to exhaust-gas toxic components emission. Journal of KONES Internal Combustion Engines, 2003, 10(1-2).

[11] VIERLING, F. Modern performance and emission test procedures - principles, technology, application. Bad Wörishofen. 2010.

[12] MAHA, MSR single roller dynamometer. Original Operating Instructions. 2011.

[13] KURANC, A. Chosen examples of investigations upon the combustion engines taken with the modern diagnostic testers, Eksploatacja silników spalinowych. 2007.

Wiesław Piekarski, DSc., DEng. - Faculty of Production Engineering at University of Life Sciences in Lublin.

e-mail: Wieslaw.Piekarski@up.lublin.pl
[14] MAHA, Motor gas tester MGT 5 five-gas tester. Technical Handbook. 1999.

[15] Dz. U. UE L42, Tom 55, Regulamin nr 83 Europejskiej Komisji Gospodarczej Organizacji Narodów Zjednoczonych (EKG ONZ) - Jednolite przepisy dotyczące homologacji pojazdów w zakresie emisji zanieczyszczeń w zależności od paliwa zasilającego silnik. 2012.

[16] KURANC, A. Exhaust emission test performance with the use of the signal from air flow meter. Eksploatacja $i$ Niezawodnosc - Maintenance and Reliability. 2015, 17(1).

[17] DIESELNET, Emission Standards: Europe: Cars and light trucks, 2017. [Online]. Available: /www.diesel-net.com/ standards/eu/ld.php\#stds (accessed: 24.03.2017).

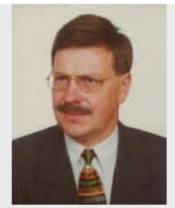

Andrzej Kuranc, DEng. - Faculty of Production Engineering at University of Life Sciences in Lublin.

e-mail: Andrzej.Kuranc@up.lublin.pl 